\title{
Factors Holding Back Small Third Sector Organizations' Engagement with the Local Public Sector
}

\author{
Piers Thompson \\ Nottingham Business School, $8^{\text {th }}$ Floor Newton Building, Nottingham Trent \\ University, 50 Shakespeare Street, Nottingham, NG1 4FQ. \\ Email: piers.thompson@ntu.ac.uk \\ Robert Williams \\ National Entrepreneurship Observatory \\ Email: rwillia6@hotmail.com \\ Caleb Kwong \\ University of Essex \\ Email: ckwong@essex.ac.uk
}

\begin{abstract}
In many developed countries there has been a shift from grants to contracts as a source of local public sector funding of the third sector. Smaller third sector organizations may struggle to compete for this funding due to the complex process of accessing and maintaining this funding and conveying their capabilities to funding providers. This study utilizes data from the UK to determine what factors increase these administrative and communication barriers for smaller organizations. Resources in terms of income and volunteers affect perceptions of the process of obtaining funding. A solution may be standardization of evaluation and monitoring, but this may lead to isomorphism and loss of variety of provision. Better two way communication may allow local authorities retain variety in public service provision through improved knowledge of their partners.
\end{abstract}

This is the peer reviewed version of the following article:

Thompson, P. Williams, R. and Kwong, C. (2017) 'Factors Holding Back Small Third Sector Organizations' Engagement with the Local Public Sector', Nonprofit Management and Leadership, doi:10.1002/nml.21260

which has been published in final form at:

http://dx.doi.org/10.1002/nml.21260

This article may be used for non-commercial purposes in accordance with Wiley Terms and Conditions for Self-Archiving. 


\title{
Factors Holding Back Small Third Sector Organizations' Engagement with the
}

\section{Local Public Sector}

\begin{abstract}
In many developed countries there has been a shift from grants to contracts as a source of local public sector funding of the third sector. Smaller third sector organizations may struggle to compete for this funding due to the complex process of accessing and maintaining this funding and conveying their capabilities to funding providers. This study utilizes data from the UK to determine what factors increase these administrative and communication barriers for smaller organizations.

Resources in terms of income and volunteers affect perceptions of the process of obtaining funding. A solution may be standardization of evaluation and monitoring, but this may lead to isomorphism and loss of variety of provision. Better two way communication may allow local authorities retain variety in public service provision through improved knowledge of their partners.
\end{abstract}

\section{Introduction}

The third sector is seen as a key contributor in providing public services in many developed countries including: Australia (Furneaux and Ryan 2014), Germany (Bode and Brandsen 2014), Italy (Ranci 2015), US (Garrow 2010; Pettijohn et al. 2013), and UK (Clifford, Geyne-Rahme, and Mohan 2013). It has the advantage of being able to more successfully engage with hard to reach groups (Lu 2015; Fyffe 2015). However, when attempting to access public funds third sector organizations struggle to compete with private and public sector providers on a pure financial basis and must emphasize their additional social contribution (Arvidson 2009; Flockhart 2005). For smaller third sector organizations with fewer resources, highlighting their full impact to show their additional value is problematic (Bovaird 2014; Osborne and Super 2010; Ranci 2015).

Much of the work examining these difficulties faced by smaller third sector organizations relies on smaller case studies (Senyard et al. 2007), and less attention has been paid to examining which factors have the greatest influence, be these internal resources or external environmental factors (Kendall and Knapp 2000; 
Westall 2009). This study investigates the difficulties faced by UK third sector organizations with the fewest employees in accessing local government funding, in terms of perceived difficulties in overcoming administrative burdens and communicating successfully with the local public sector.

The analysis uses a large dataset containing information on perceptions of the environment created for the third sector in the UK, the National Survey of Charities and Social Enterprise (NSCSE). To examine which factors have the greatest effect for different sized organizations, a regression approach is adopted using subsamples based on employment.

The structure of the remainder of the paper is as follows. Section 2 covers the literature setting out the context and policy climate faced by third sector organizations looking to access public sector funding. Section 3 introduces the NSCSE data and approaches utilized to analyse organizations' satisfaction with funding arrangements and ability to communicate their value. The results of this analysis are reported in section 4 . Section 5 summarizes and examines what conclusions can be drawn from the study.

\section{Policy developments and the implications for third sector funding}

The public sector remains the largest single source of third-sector funding in many developed countries (Clifford, Geyne-Rahme, and Mohan 2013; Pettijohn et al. 2013). The last Labour Government in the UK encouraged the third sector to become involved in the provision of public services, but Carmel and Harlock (2008) argue that the policies pursued under the premise of partnership allowed governments to turn the third sector into a 'governable terrain'. This effectively 
'privatized' social provision in countries such as the US and UK (Åberg 2013; Garrow 2010; Lu 2015).

Austerity measures being pursued by governments, particularly those in the European Union have ensured the continuation of this process (Rees, Mullins, and Bovaird 2012). In the UK, the Conservative Government manifesto for 2015-2020 outlined policies to encourage third sector delivery of services including strengthening community rights and generating greater opportunities in education (academies/schools) (Conservative Party 2015). The Localism Act (Department for Communities and Local Government 2011) aimed to devolve more decision making powers to individuals, communities and councils at a local level. In addition, the 2012 Public Services (Social Value) Act (HM Government 2012) requires service commissioners in England and Wales to "have regard" to the social value when buying services. The levels of contracts covered by the Act are limited but under review (Cabinet Office 2015), increasing the importance of the relationship between local government and the third sector.

Accessing public funding may have required third sector organizations to adapt to the public sector's requirements (Thompson and Williams 2014), compromising their key attributes and values (Harris 2010), particularly where competing against other organizations (Seo, 2016). Garrow (2010) provides US evidence that the public sector benefits as there is greater collaboration and concentration on fulfilling the local government's needs. Similarly in the UK the changing funding environment has been associated with increased efficiency (Rees, Mullins, and Bovaird 2012). However, greater contact and collaboration with the public sector provides legitimacy and security (Garrow 2010). 
Although, there is no legal requirement in the UK for local government to put contracts out to competitive tender, this is becoming more common with procurement commissioners showing a preference to award contracts to a single supplier (Rees, Miller, and Buckingham 2014). One consequence of a move from grants to contracts has been that third sector organizations have had to learn how to compete with the private sector (Bode and Brandsen 2014; Metcalf 2013; Rees, Mullins, and Bovaird 2012). This contrasts with the US experience where state agencies indicate that nonprofits face little competition from other nonprofits or the private sector (Fyffe 2015). The third sector may be at a disadvantage in tendering for public sector contracts compared to private sector providers because of a lack of experience, alongside commitments which raise costs, such as high quality working environments (Osborne and Super 2010). Smaller resource constrained organizations may struggle to generate social value (Di Domenico and Haugh 2007), and as outputs take time to work, prove their activities' full impact (Mook, Chan, and Kershaw 2015). Where social value cannot be shown Bovaird (2014) indicates that emphasis is placed on economies of scale rather than scope, which favors granting of contracts to larger third sector organizations losing the diversity provided by smaller organizations.

The third sector communicates its own role and the needs of society through its participation and advocacy roles (Lu 2015). However, the small scale of many organizations limits their visibility and power to influence policy makers with only a small elite having such power (Buckingham et al. 2014). Lu (2015) shows the importance of formal and informal communication with government sources in regard to obtaining government funding. This communication can be disrupted where high 
staff turnover breaks relationships between the third and public sectors, a problem particularly found for smaller nonprofits (Fyffe 2015).

Access to public funds has led to an emphasis on accountability and transparency (Dacombe 2011), and more comprehensive evaluations by funding providers (Arvidson 2009; Ellis and Gregory 2008). Effectively a greater application of outcome-based approaches linked to payment by results (Rees, Mullins, and Bovaird 2012). This means undertaking impact assessments (Metcalf 2013), and adopting auditing practices introduced through the passing of legislation (HM Government 2012).

US evidence indicates that the complexity of administration affects a majority of those organizations receiving public funding, particularly when from multiple sources (Pettijohn et al. 2013). To aid third sector organizations, the UK government provides guidance on conducting impact evaluations (HM Treasury 2011), but many lack the resources and skills to undertake such activities (Ellis and Gregory 2008; Mitchell and Berlan 2016; Thompson and Williams 2014). There are rarely resources provided to undertake evaluations, meaning funds are diverted from core activities (Carman and Fredericks 2008; Wainwright 2002). This burden will be greater where individual funders have different requirements (Pettijohn et al. 2013). The extent that limited financial resources hinder smaller third sector organizations is unclear. If it is purely the cost of administrating public funding sources or measuring impact then the solution may be to require all contracts to include funding for this purpose (Carman and Fredericks 2008).

The smaller community based organizations that reflect the perceived strengths of the third sector are disadvantaged to the greatest extent by the move to a more competitive structure with additional administrative requirements (Ellis and 
Gregory 2008; Fyffe 2015; Osborne and Super 2010). The success of such organizations is based on their volunteers who are likely to lack the skills (Millar and Hall 2013), and inclination to manage contracts (Ellis Paine, Ockenden, and Stuart 2010; Milligan and Fyfe 2005). Attempts to professionalize may meet with considerable resistance and is inappropriate for smaller less formalized organizations (Milligan and Fyfe 2005). Where professionalization occurs, tensions may exist between volunteers and skilled employees (Doherty, Haugh, and Lyon 2014). Nevertheless even in Italy, which has traditionally had smaller more informal third sector organizations, there is evidence of increased professionalization (Ranci 2015).

The move from grants to contracts and the need to provide evidence of value for money are likely to promote some third sector organizations and marginalize others (Schreiner 2002). This study attempts to isolate what factors play the greatest role in raising/overcoming administrative burdens and promoting/hindering communication between the third and local public sectors.

\section{Data and Methods}

The longitudinal element of US tax return data has been used to infer the changing behavior of organizations in response to policy interventions (Calabrese 2013). However, third sector perceptions of difficulties in accessing public finance is absent, meaning the conclusions drawn will be open to question. Tax return data also provides no insight into organizations' abilities to convey their value or influence public sector partners. An alternative data source is required that more directly captures such perceptions. This section outlines the data used in this study, the operationalization of measures, and analysis applied. 
The National Survey of Charities and Social Enterprises (NSCSE) data

The data used are from the 2010 National Survey of Charities and Social Enterprises (NSCSE) (Cabinet Office et al. 2008), originally collected by Ipsos MORI, Social Research Institute, and GuideStar UK, and funded by the Cabinet Office, Office of the Third Sector to capture the extent that local government provides an environment for a thriving third sector (Ipsos MORI and Social Research Institute 2009). A sampling frame of approximately 129,000 charities and 40,000 other organizations based in England was defined by Guidestar UK, based on data available from Charities Commission and data directly supplied by third sector organizations. To obtain local authority values with the confidence intervals required by the Office for Charities and Social Enterprises in 42 local authorities a stratified sample approach was taken for charities based on their income. For the remaining 109 local authority areas all third sector organizations were surveyed. This means 112,796 organizations were selected to take part in the survey. There were 44,109 responses giving an overall response rate of 41 percent (Ipsos MORI and Social Research Institute 2009). This means there is coverage of all third sector organizations in England not just the largest, unlike, for example, the Urban Institute's national survey of the US which focuses only on organizations with expenditure of $\$ 100,000$ or more (Pettijohn et al. 2013), allowing the experiences of the smallest third sector organizations to be compared to their larger counterparts.

The survey data provided just over 10,000 observations $(N=10,695)$ with all required information. Missing responses were associated with items relating to satisfaction with applying for grants (25,062 missing responses), help, support and 
advice in applying for grants (24,115 missing responses), and administration of receiving grants and contracts $(26,934)$. The analysis includes both organizations that have and have not received local government funding, but it may mean that the remaining data is skewed towards those with more experience and interaction with local government. However, this may lead to these responses being more accurate representations of organizations' experiences. There were also missing data for some control variables used in the analysis, such as, income (5083 missing responses) and the number of volunteers (2955 missing responses). This missing data meant that whilst the variables included in the analysis were based on their theoretical influence, other variables such as whether 'organizations felt they needed support' were not included as this would have further reduced the observations available. Unfortunately the NSCSE was last undertaken in 2010 and more recent changes in policy may affect the results found here. As the NSCSE does not include organization identifiers it is not possible to track organizations and capture longitudinal elements.

Measures of Difficulties Accessing Public Funds and Communication

Items capturing organizations' perceptions of the problems of administrative complexity and difficulties accessing finance highlighted in Section 2 (Ellis and Gregory 2008; Pettijohn et al. 2013) were captured by respondents' satisfaction with:

- The process involved in applying for funding/bidding for contracts

- The help, advice and support provided by local statutory bodies when applying for grants/bidding for contracts

- The administration involved in receiving local funding/maintaining contracts 
These were registered using a five point scale running from very satisfied through to very dissatisfied. As responses were skewed towards dissatisfaction the very satisfied and fairly satisfied categories were combined into a single category.

To examine the issue of smaller third sector organizations' limited ability to convey their role and communicate with the local public sector (Buckingham et al. 2014; Fyffe 2015; Lu 2015), the degree of agreement with the four items below were used:

- Local statutory bodies in your local area value the work of your organization

- Local statutory bodies in your local area understand the nature and role of your organization

- Local statutory bodies in your local area consult your organization on issues which affect you or are of interest to you

- Local statutory bodies in your local area involve your organization appropriately in developing and carrying out policy on issues which affect you A five point scale was used to record organizations' responses ranging from strongly agree to strongly disagree.

As the individual items in the two groups are likely to be related we create two composite measures capturing the satisfaction with the process of acquiring and maintaining local government funding, and perceptions that the third sector is understood. Principal component analysis (PCA) with a varimax approach is applied to produce distinct and easy to identify components. The seven variables loaded onto two components representing the two groups above with eigenvalues of more than 1 (Kaiser, 1960) (see Appendix Table A1). Factor scores were calculated using the Anderson-Rubin approach. 
To understand which factors play the greatest role a regression approach is adopted, using the composite measures of 'satisfaction with the process of acquiring and maintaining funding' and 'perception that the third sector organization can communicate and is understood' used as the dependent variables. Jaskyte (2013) found in capturing the expertise required to generate innovations employment based measures of size appeared more appropriate than financial measures. Human resources might be expected to have similar relevance for the issues under investigation here, so the sample is broken into three groups, those with: no full-time employees; one to five employees; and six or more employees. The main group of third sector organizations of interest are those with no employees, but equivalent calculations are run for the other subgroups for comparative purposes. To capture the resources available beyond employees we include the natural logs of income and number of volunteers. The variance inflation factors (VIF) indicate there is no problem with multicollinarity.

\section{Other Independent Variables}

Other characteristics which may influence third sector organizations' ease of access to funding and public profile include: the legal form of the organization, charity or non-charity (community interest company, company limited by guarantee, industrial and provincial society); scale of operations, local, regional, national and international; main groups being served, minority groups, the general public, victims of crime or drug abuse, those with mental or physical difficulties, and children or those caring for 
them. The legal form may indicate an organization's activities, which may influence its profile and compatibility with public sector contracts (Charity Commission 2007; Chew 2010). Organizations operating over a larger geographical area may have a higher profile, overcoming the informational asymmetry with the public sector (Milbourne 2009).

The main groups served by organizations' may influence their access to finance and whether their role is understood and valued. Serving harder to reach groups will increase an organization's value (Wainwright 2002), but they may not feel their full value is appreciated (Westall 2009). PCA was utilized to identify the groups served (for details please see Appendix 1).

We control for the deprivation of the organizations' location using the index of multiple deprivation (McLennan et al. 2011). The need for third sector services may be greater in deprived areas (Byrne, Adamson, and Bromiley 2006), but with limited potential to pay for services (Seelos, and Mair 2005). Thus, more public funding may be available to tackle the problems faced in deprived areas (Clifford et al., 2013; Luksetich, 2008). However, the lack of other community resources can also hold back third sector organizations in such locations (Sellick, 2014), which may hinder their capability to interact and gain funding from local government. This makes the overall effect of environment theoretically uncertain and with little empirical agreement between the prior studies outlined above.

Responses with regard to satisfaction with funding arrangements could be from experience of administrating local government funding, or alternatively the (perceived) difficulties of obtaining the funding. To help isolate the understanding of the administrative burden we control for whether the organizations have received local government funding in the last five years. Alternatives, such as, controlling for 
current public funding or bidding for public funding had minimal effects on the results, but were less appropriate in capturing recent experience of managing local government funding. This control is also included for the regressions of communication and understanding as receiving such funding may improve links between the third sector and local government.

\section{Results}

There is a relatively high level of dissatisfaction shown for all the aspects of the process of accessing public funding (Table 1). Just under half (49.2 per cent) of the organizations indicate they are somewhat dissatisfied with the process of funding (Panel a) and 43.9 per cent with the administration involved (Panel c). Dissatisfaction with support and advice is lower, but still approaches two in five of those surveyed (38.1 per cent).

\section{PLEASE INSERT TABLE 1 ABOUT HERE}

With regard to the process of applying (Panel a) and support and advice (Panel b) the smallest organizations are those with the largest proportion satisfied, although the proportions vary only slightly. The relationships are not always monotonic, for instance the middle group of organizations ( 1 to 5 employees) display the lowest proportion satisfied (24.5 percent) with the process of applying for funding (Panel a). This is reflected in the Gamma statistic, which is close to zero $(-0.036)$, but negative and significant suggesting that satisfaction with the process is negatively related to size. For satisfaction with the support and advice the difference is clearer with the smallest organizations (no employees) having 37.4 per cent satisfied and the largest (six or more employees) having 30.6 per cent satisfied. This is reflected in the significantly negative Gamma statistic, but it should also be noted that a slightly 
larger proportion of the smallest organizations are very dissatisfied. The smallest organizations appear to have more extreme perceptions of support and advice. In contrast the proportion of organizations satisfied with the administration of funding displays the opposite pattern (Panel c), with the smallest least satisfied, 27.5 per cent (no employees) compared to 31.2 per cent (six or more employees). Here a weak significant positive association is found between size and satisfaction with administration $(G a m m a=0.022)$. This makes the administrative burden the issue which holds back smaller organizations the most (Ellis and Gregory 2008; Fyffe 2015), which support cannot necessarily overcome.

In terms of communication, a majority (64.3 per cent) of all third sector organizations agree that their work is valued by local government (Table 2). There is more doubt with regard to perceptions they are understood by the local public sector (Panel b), with over a quarter disagreeing (27.3 per cent). The story is similar for consultation about important issues (Panel c) and involvement in policy development (Panel d), only a minority feel appropriately engaged (39.8 per cent and 32.6 per cent respectively).

\section{PLEASE INSERT TABLE 2 ABOUT HERE}

As predicted it is the smaller organizations with lower public profiles that perceive the greatest communication and collaboration difficulties (Bovaird 2014; Buckingham et al. 2014). The Gamma statistics confirm a significant positive association between agreement about communication and understanding with organization size for all measures. However, there is little difference in the percentage agreeing about local government's understanding of the third sector's nature (Panel b). In contrast in Panel $c$ the percentage indicating there is consultation on issues rises from 34.6 per cent (no employees) to 45.2 per cent (six or more employees). 
To understand what factors are associated with lower satisfaction with the funding process, and communication and understanding for the smallest third sector organizations compound measures capturing the overall difficulties faced are used in the regressions reported below (Tables 3 and 4). Although the regressions explain a relatively small proportion of the variance, the F-tests do reject the null of collective insignificance.

\section{PLEASE INSERT TABLE 3 ABOUT HERE}

The Gamma statistics reported in Table 1 indicate that smaller third sector organizations are linked to greater dissatisfaction with administration of grants and contracts rather than with the process of obtaining grants and support available. However, these organizations still have the highest proportions reporting dissatisfaction with these earlier stages. With monitoring and evaluation imposing a disproportionately large burden on smaller organizations it is unsurprising that financial resources are positively associated with perceptions about the process of applying for and maintaining local funding sources for this subgroup only (Wainwright 2002). The absence of such a result for larger organizations is consistent with Jaskyte's (2013) examination of the relationship between size and innovation where income has a limited effect in overcoming resource limitations. For the largest organizations a negative relation with income could reflect management diseconomies of scale where smaller local funding sources are less suited to larger organizations (Bovaird 2014). The negative relationship with geographical scope would also fit with this with more embedded local organizations showing greater satisfaction with the funding arrangements. 
In the UK context, it has been suggested that funding is biased against smaller organizations, (Keen, 2015) with 139,000 of the small and micro organizations receiving only 3 percent of the total statutory income, as opposed to 81 percent received by 4558 organizations with an income of $£ 1$ million or more (NCVO, 2012). Due to the intense competition, demonstrating financial viability appears of greater importance in relation to smaller non-profits' funding. Volunteers with their limited role, or desire to be involved, in business or management functions have a negative effect (Ellis Paine, Ockenden, and Stuart 2010; Milligan and Fyfe 2005). New contracts available may have moved away from the types of grants that were suited to the smaller traditional third sector organizations who are reliant on volunteers. Those engaging with the public sector may have less tradition of relying on volunteers and are engaging in the process of professionalization, replacing volunteers with staff (Ranci 2015).

Larger organizations supporting the young and their carers are more satisfied, which may reflect the availability of funding for these groups (Luksetich 2008), however, for smaller organizations this is reversed implying they struggle to overcome the complex administration for specialized funding (Senyard et al. 2007). Regardless of size those supporting minority groups display less satisfaction. Worryingly those third sector organizations taking forms other than charities are negatively affected. This may be because certain sources of grant funding in the UK are only available for those with charitable status (NCVO 2016). Some dissatisfaction with local government funding arrangements clearly comes from a lack of experience with those successfully accessing such funding in the past having more positive views. 


\section{PLEASE INSERT TABLE 4 ABOUT HERE}

A positive association between organization size and the measures of communication and understanding as was indicated by the Gamma values in Table 2, so it would appear smaller third sector organizations feel less well understood and unable to influence policy. Resources such as income and volunteers did not have a significant impact on alleviating this problem. However, for smaller third sector organizations not being a charity does have a negative effect, which is consistent with difficulties in conveying their complex non-typical role in society, being hindered further due to a lack of resources (Chew 2010). For the third sector as a whole prior experience and interaction may be vital as where funding was received in the past there is a more positive perspective with regard to communication and understanding. Interestingly in both sets of regressions the level of local deprivation has limited influence. As outlined in Section 3 this may reflect two counteracting forces, greater potential need and public funding available for the third sector, offset by a lack of other local third sector and community resources to support it (Clifford et al., 2013; Luksetich, 2008; Sellick, 2014).

\section{Discussion and Conclusions}

This study sought to identify what factors were linked to smaller third sector organizations' dissatisfaction with access to public funding and the extent that they were able to communicate with local government to aid access to these funds through greater understanding. Smaller organizations with fewer employees were more likely to be dissatisfied with the administration associated with local government authority funding and feel their outputs and role in society were 
misunderstood. The regression analysis was consistent with the theory outlined in section 2, which suggested a lack of resources may hinder smaller organizations in dealing with this administration. Small non-charities in particular struggled to communicate with local government to boost understanding of their social value.

In interpreting the results we must note that the measure used in this paper that considers satisfaction with administration linked to accessing and maintaining funding is a broad measure. This means that it could capture a variety of aspects in the process and does not specifically relate to any particular issues. However, the existing literature has consistently highlighted impact evaluations as a one of the most relevant administrative burdens associated with grants (Ellis and Gregory 2008; HM Government 2012; Metcalf 2013; Thompson and Williams 2014). Therefore it is wise to consider the results in the light of this existing work and how such burdens may be alleviated. One possible solution is to provide training in techniques of valuing non-market goods and analysing the results of impact assessments (Ellis and Gregory 2008), but the role of internal resources found in the regressions implies training costs are likely to be beyond many smaller third sector organizations (Millar and Hall 2013). The UK Government has created the Investment and Contract Readiness Fund (ICRF) dedicated to helping nonprofits acquire the skills required to compete for public service contracts and has been linked to $£ 117$ million of contracts awarded (Brown and McAllister 2014). However, only a relatively small proportion of organizations have benefited so far. The effective implementation of the Social Value Act will ensure good practice in commissioning and providing social value (Cabinet Office 2016).

Local government is shown to need forums to meet all, but particularly smaller, third sector organizations to improve the communication flows (Huxham and 
Vangen 1996). This chimes with Lu's (2015) recommendation that when seeking public funds organizations ensure domain consensus is achieved through boundary spanning activities, such as allocating resources to networking. Two way communication will ensure both parties understand what is perceived to create social value and how this can be reported particularly for non-typical nonprofits such as social enterprises (Fyffe 2015). Third sector organizations will benefit from legitimization (Garrow 2010), whilst local government can benefit from the third sector fulfilling their needs better (Garrow 2010; Smith and Grønbjerg 2006). Without this local governments may become relatively more familiar with their existing partners as prior funding was found to be key in communication and understanding (Ellis and Gregory 2008; Fyffe 2015; Kendall and Knapp 2000; Lu 2015). Without this a division between professionalized haves, and voluntary-based have nots may develop (Ranci 2015).

A solution combining both insights from the results of this study would be to shift the burden of monitoring and evaluation to the local government, ideally at the functional economic level. This would ensure skilled personnel could undertake monitoring and evaluation costs across the area, benefitting from economies of scale. Reduced costs would allow the net value to the third sector to be increased, and would allow smaller community based organizations to concentrate on their core activities. However, evaluating diverse activities, organizations and local contextual environments in a uniform manner has a danger that organizations will lose their identity and copy those seen as displaying best practice, losing the variety that is seen as a strength of the third sector (Fyffe 2015). It is, therefore, important that small third sector organizations play an advisory role in such a body. An alternative approach is the 'free customer model', used particularly in German and Dutch elderly 
care (Bode and Brandsen 2014) and introduced recently in Italian third sector (Ranci 2015). Public money is given to users to spend, which shifts the burden of determining the social value of services from the local government to those that benefit directly. This may lead to less homogenization than the pre-fixed output and performance standards used more widely in the UK, Canada and US. Smaller less professionalized organizations are still likely to require some direct support and funding (Ranci 2015).

The study is limited as it is impossible to determine all the factors that influence a third sector organization's ability to communicate its value to local authorities using only a restricted set of organization characteristics. In-depth research over a period of time embedded within the organizations would provide a better understanding of this communication. It would allow issues of past experience of managing such funding to be split from difficulties accessing the funding in the first place. This would allow more understanding of the problems faced, in a similar manner to some of the items used in the Urban Institute's US study (Pettijohn et al. 2013). A greater insight may come from examining the specific measures within the NSCSE data rather than the composite measures created. The results here apply the UK and it would be of value to undertake similar work in differing public funding environments. The NSCSE data used is five years old and unlikely to be repeated, which means it does not incorporate the latest policy developments. Focused studies on specific recent policy interventions' impact on the smallest nonprofits would be of value.

The study has shown that smaller third sector organizations are likely to struggle to meet the requirements of public sector contracts. It seems that the administrative burden in combination with limited communication for smaller 
organizations will restrict their access to resources. Unless this is rectified the danger is that third sector activity may become focused in a smaller number of larger less embedded organizations. This may result in more limited provision of services with less choice, which is one of the ways that third sector organizations' success should be measured (Kendall and Knapp 2000). To overcome this funding for social impact measurement training and evaluations needs to be made available, and its use informed by a healthy interaction and collaboration between small third sector organizations and local government.

\section{References}

Åberg, P. 2013. "Managing Expectations, Demands and Myths: Swedish Study Associations Caught between Civil Society, the State and the Market." Voluntas 24 (3): 537-58.

Arvidson, M. 2009. "Impact and Evaluation in the UK Third Sector: Reviewing Literature and Exploring Ideas." Third Sector Research Centre Working Paper no. 27. University of Birmingham.

Bode, I., and T. Brandsen. 2014. "State-third Sector Partnerships: A Short Overview of Key Issues in the Debate." Public Management Review 16 (8): 1055-66.

Bovaird, T. 2014. "Efficiency in Third Sector Partnerships for Delivering Government Services: The Role of Economies of Scale, Scope and Learning." Public Management Review 16 (8): 1067-90. 
Brown, A. and K. McAllister. 2014. Ready, Willing and Able: An Interim Review of the Investment and Contract Readiness Fund, London: Boston Consulting Group.

Buckingham, H., A. Ellis Paine, P. Alcock, J. Kendall, and R. Macmillan. 2014. “Who's Speaking for Whom? Exploring Issues of Third Sector Leadership, Leverage and Legitimacy." Third Sector Research Centre Working Paper, no. 121. University of Birmingham.

Byrne, P., D. Adamson, and R. Bromiley. 2006. Towards a New Mixed Economy: An Exploration of the Relationship between Social Enterprise and Private Sector Micro and Small to Medium Enterprises (SMEs) in Wales. Pontypridd: University of Glamorgan.

Cabinet Office. 2015. Social Value Act Review - Report. London: Cabinet Office.

Cabinet Office. 2016. Social Value Act: Information and Resources. Updated 20 London: Cabinet Office.

Cabinet Office. Office of the Third Sector, Ipsos MORI. Social Research Institute and GuideStar UK, National Survey of Third Sector Organisations. 2008. [computer file]. Colchester, Essex: UK Data Archive [distributor], March 2010. SN: 6381, http://dx.doi.org/10.5255/UKDA-SN-6381-1.

Calabrese, T. 2013. "Running on Empty: The Operating Reserves of U.S. Non-profit Organizations." Nonprofit Management and Leadership 23 (3): 281-302. 
Carman, J. G., and K. A. Fredericks. 2008. "Nonprofits and Evaluation: Empirical Evidence from the Field." New Directions for Evaluation 118: 51-71.

Carmel, E., and J. Harlock. 2008. "Instituting the 'Third Sector' as a Governable Terrain: Partnership, Procurement and Performance in the UK." Policy and Politics 36 (2): 155-71.

Cattell, R. B. 1966. "The Scree Test for the Number of Factors." Multivariate Behavioural Research 1 (2): 245-76.

Charity Commission. 2007. Trustees, Trading and Tax: How Charities may Lawfully Trade. London: Charity Commission.

Chew, C. 2010. "Strategic Positioning and Organizational Adaptation in Social Enterprise Subsidies of Voluntary Organizations: An Examination of Community Interest Companies with Charitable Origins." Public Management Review 12 (5): 609-34.

Clifford, D., F. Geyne-Rahme, and J. Mohan. 2013. "Variations between

Organisations and Localities in Government Funding of Third-sector Activity:

Evidence from the National Survey of Third-sector Organisations in England." Urban Studies 50 (4): 959-76. 
Conservative Party. 2015. The Conservative Party Manifesto 2015. London:

Conservative Party.

Dacombe, R. 2011. "Can We Argue Against It? Performance Management and State Funding of Voluntary Organizations in the UK." Public Money and Management 31 (3): 159-66.

Department for Communities and Local Government. 2011. A Plain English Guide to the Localism Act. London: Department for Communities and Local Government.

Di Domenico, M. L., and H. Haugh. 2007. "Strategic Partnering: Results from a Survey of Social Ventures in the UK." Paper presented at the International Social Entrepreneurship Research Conference, Copenhagen, June 18-19.

Doherty, B., H. Haugh, F. Lyon. 2014. "Social Enterprises as Hybrid Organizations: A Review and Research Agenda." International Journal of Management Reviews 16 (3): 417-36

Ellis, J., and T. Gregory. 2008. Accountability and Learning: Developing Monitoring and Evaluation in the Third Sector. London: Charities Evaluation Services.

Ellis Paine, A., N. Ockenden, and J. Stuart. 2010. "Volunteers in Hybrid Organizations: A Marginalised Majority?" In Hybrid Organizations and the Third Sector: Challenges for Practice, Theory and Policy, edited by D. Billis. Basingstoke: Palgrave MacMillan. 
Flockhart, A. 2005. "Raising the Profile of Social Enterprises: The use of Social Return on Investment (SROI) and Investment Ready Tools (IRT) to Bridge the Financial Credibility Gap." Social Enterprise Journal 1 (1): 29-42.

Furneaux, C., and N. Ryan. 2014. "Modelling NPO-government Relations: Australian Case Studies." Public Management Review 16 (8): 1113-40.

Fyffe, S. D. 2015. Nonprofit-Government Contracts and Grants: The State Agency Perspective, Washington DC: Urban Institute.

Garrow, E.E. 2010. "Receipt of Government Revenue Among Non-profit Human Service Organizations." Journal of Public Administration Research and Theory 21 (3): 445-71.

Harris, M. 2010. "Third Sector Organizations in a Contradictory Policy Environment." In Hybrid Organisations and the Third Sector: Challenges for Practice, Theory and Policy, ed. D. Billis, Basingstoke: Palgrave Macmillan.

HM Government. 2012. Public Services (Social Value) Act 2012. London: The Stationary Office.

HM Treasury. 2011. The Magenta Book. Guidance for Evaluation. London: HM Treasury. 
Huxham, C., and S. Vangen. 1996. "Working Together: Key Themes in the Management of Relationships between Public and Non-profit Organisations." International Journal of Public Sector Management 9 (7): 5-17.

Ipsos MORI and Social Research Institute. 2009. National Survey of Third Sector Organisations: Technical Report. London: Ipsos.

Jaskyte, K. 2013. “Does Size Really Matter? Organizational Size and Innovations in Nonprofit Organizations." Nonprofit Management and Leadership 24 (2): 229-47.

Kaiser, H. F. 1960. "The Application of Electronic Computers to Factor Analysis." Educational and Psychological Measurement 20 (1): 141-51.

Keen, R. (2015) Charities and the Voluntary Sector: Statistics. House of Commons Briefing Paper, Number SN05428.

Kendall, J., and M. Knapp. 2000. "Measuring the Performance of Voluntary Organizations." Public Management 2 (1): 105-32.

Lu, J. 2015. 'Which Nonprofit gets more Government Funding? Nonprofits' Organizational Attributes and their Receipts of Government Funding." Nonprofit Management and Leadership 25 (3): 297-312.

Luksetich, W. 2008. "Government Funding and Nonprofit Organizations." Nonprofit and Voluntary Sector Quarterly 37 (3): 434-42. 
McLennan, D., H. Barnes, M. Noble, J. Davies, E. Garratt, and C. Dibben. 2011. The English Indices of Deprivation 2010. London: Department for Communities and Local Government.

Metcalf, L. 2013. "Measuring Impact: How can Third Sector Organisations make sense of a Rapidly Expanding Marketplace of Tools?" Third Sector Research Centre (TSRC) Working Paper, no. 111. University of Birmingham.

Milbourne, L. 2009. "Remodelling the Third Sector: Advancing Collaboration or Competition in Community-based Initiatives?" Journal of Social Policy 38 (2): 277-97.

Millar, R., and K. Hall. 2013. "Social Return on Investment (SROI) and Performance Measurement: The Opportunities and Barriers for Social Enterprise in Health and Social Care." Public Management Review 15 (6): 923-41.

Milligan, C., and N. Fyfe. 2005. "Preserving Space for Volunteers: Exploring Links between Voluntary Welfare Organizations, Volunteering and Citizenship." Urban Studies 42 (3): 417-33.

Mitchell, G. E., and D. Berlan. 2016. "Evaluation and Evaluative Rigor in the Nonprofit Sector." Nonprofit Management and Leadership doi: 10.1002/nml.21236 
Mook, L., A. Chan, and D. Kershaw. 2015. "Measuring Social Enterprise Value Creation: The Case of Furniture Bank." Nonprofit Management and Leadership 26 (2), 189-207.

NCVO (2012) UK Civil Society Almanac, What are the Main Trends in Statutory Funding? 33.

NCVO (2016) Pros and Cons of Becoming a Charity. Accessed from: https://knowhownonprofit.org/basics/setting-up-a-charity/charitablestatus/pros and cons of becoming a charity. Accessed on 30 August 2016.

Osborne, S. P., and B. Super. 2010. Scoping Study on the Third Sector in Scotland, Centre for Public Services Research. Edinburgh: University of Edinburgh Business School.

Pettijohn, S. L, E. T. Boris, C. J. De Vita, and S. D. Fyffe. 2013. Nonprofitgovernment Contracts and Grants: Findings from the 2013 National Survey, Washington DC: Urban Institute.

Ranci, C. 2015. "The Long-term Evolution of the Government-third Sector Partnerships in Italy: Old Wine in a New Bottle?" Voluntas 26 (6), 2311-29.

Rees, J., D. Mullins, and T. Bovaird. 2012. "Third Sector Partnerships for Public Service Delivery: An Evidence Review." Third Sector Research Centre Working Paper no. 60. University of Birmingham 
Rees, J., R. Miller, and H. Buckingham. 2014. "Public Sector Commissioning of Local Mental Health Services from the Third Sector." Third Sector Research Centre Working Paper no. 122. University of Birmingham.

Schreiner, M. 2002. "Aspects of Outreach: A Framework for the Discussion of the Social Benefits of Microfinance." Journal of International Development 14, 1-13.

Seelos, C., and J. Mair. 2005. "Social Entrepreneurship: Creating New Business Models to Serve the Poor." Business Horizons 48 (3): 241-46.

Sellick, J. 2014. "The Rural Big Society and (changing) Public Service Delivery: A Case Study of Jubilee Park." Local Economy 29 (1/2): 163-69.

Senyard, J., D. Pickernell, N. C. Clifton, and M. J. Christie. 2007. "Grant Maintained or Grant Restrained? Rural Social Enterprise in Ceredigion Wales." Journal of Rural Enterprise and Management 3 (1): 5-23.

Seo, J.W. 2016. “Resource Dependence Patterns and Organizational Behavior/Structure in Korean Nonprofit Organizations." Nonprofit Management and Leadership doi: 10.1002/nml.21235

Smith, S. R. and K. A. Grønbjerg. 2006. "Scope and Theory of Government Nonprofit Relations." In The Nonprofit Sector: A Research Handbook $2^{\text {nd }}$ Edition, edited by W. W. Powell and R. Steinberg New Haven, CT: Yale University Press. 
Tabachnick, B. G., and L. S. Fidell. 2007. Using Multivariate Statistics: $5^{\text {th }}$ Edition. Boston: Allyn and Bacon.

Thompson, P., and R. Williams. 2014. "Taking Your Eyes off the Objective: The Relationship between Income Sources and Satisfaction with Achieving Objectives in the UK Third Sector." Voluntas 25 (1): 109-37.

Wainwright, S. 2002. Measuring Impact - A Guide to Resources. London: National Council for Voluntary Organisations.

Westall, A. 2009. "Value and the Third Sector: Working Paper on Ideas for Future Research." Third Sector Research Centre Working Paper, no. 25. University of Birmingham. 


\section{Appendix 1 - Identification of main groups served by organizations}

Organizations were asked to indicate up to three groups of users of their goods and services. To overcome issues of multicollinearity where groups suffering similar issues are served by the same organization principal components analysis was used to identify broader groups of clients (Appendix Table A2). A maximum likelihood approach was adopted using the varimax orthogonal rotation to obtain uncorrelated components and ensure easier interpretation. The factor scores were estimated using the Anderson-Rubin approach to obtain non-correlated factor scores (Tabachnick and Fidell 2007). The scree plot's inflexion point was used to determine the number of factors extracted (Cattell 1966), with four selected (minority groups; general public; those with physical and mental disabilities; young people and their carers). 
Table 1 - Satisfaction levels with aspects of the application for and maintenance of Local Authority funding

\begin{tabular}{|c|c|c|c|c|c|}
\hline $\begin{array}{c}\text { Panel a - Satisfaction } \\
\text { with Process of Applying } \\
\text { for Funding }\end{array}$ & $\begin{array}{c}\text { Very } \\
\text { dissatisfied }\end{array}$ & $\begin{array}{c}\text { Fairly } \\
\text { dissatisfied }\end{array}$ & $\begin{array}{c}\text { Neither } \\
\text { satisfied } \\
\text { nor } \\
\text { dissatisfied }\end{array}$ & Satisfied & $\mathrm{N}$ \\
\hline No Employees & $20.4 \%$ & $25.4 \%$ & $26.6 \%$ & $27.5 \%$ & 3278 \\
\hline 1 to 5 Employees & $20.2 \%$ & $29.2 \%$ & $26.1 \%$ & $24.5 \%$ & 3792 \\
\hline 6 or more Employees & $19.6 \%$ & $32.4 \%$ & $22.8 \%$ & $25.2 \%$ & 3625 \\
\hline Chi-square & 49.04 & [6] & $(0.000)$ & & \\
\hline $\begin{array}{l}\text { Goodman and Kruskal's } \\
\text { Gamma }\end{array}$ & -0.036 & $\{3.030\}$ & $(0.002)$ & & \\
\hline All & $20.1 \%$ & $29.1 \%$ & $25.1 \%$ & $25.7 \%$ & 10,695 \\
\hline $\begin{array}{c}\text { Panel b - Satisfaction } \\
\text { with Support and Advice } \\
\text { Available when Applying } \\
\text { for Funding }\end{array}$ & $\begin{array}{c}\text { Very } \\
\text { dissatisfied }\end{array}$ & $\begin{array}{c}\text { Fairly } \\
\text { dissatisfied }\end{array}$ & $\begin{array}{c}\text { Neither } \\
\text { satisfied } \\
\text { nor } \\
\text { dissatisfied }\end{array}$ & Satisfied & $\mathrm{N}$ \\
\hline No Employees & $16.2 \%$ & $19.6 \%$ & $26.8 \%$ & $37.4 \%$ & 3278 \\
\hline 1 to 5 Employees & $15.6 \%$ & $23.2 \%$ & $28.0 \%$ & $33.1 \%$ & 3792 \\
\hline 6 or more Employees & $14.4 \%$ & $25.0 \%$ & $29.9 \%$ & $30.6 \%$ & 3625 \\
\hline Chi-square & 56.052 & [6] & $(0.000)$ & & \\
\hline $\begin{array}{l}\text { Goodman and Kruskal's } \\
\text { Gamma }\end{array}$ & -0.047 & $\{3.930\}$ & $(0.000)$ & & \\
\hline All & $15.4 \%$ & $22.7 \%$ & $28.3 \%$ & $33.6 \%$ & 10,695 \\
\hline $\begin{array}{l}\text { Panel c-Satisfaction } \\
\text { with Administration } \\
\text { Linked to Funding }\end{array}$ & $\begin{array}{c}\text { Very } \\
\text { dissatisfied }\end{array}$ & $\begin{array}{c}\text { Fairly } \\
\text { dissatisfied }\end{array}$ & $\begin{array}{c}\text { Neither } \\
\text { satisfied } \\
\text { nor } \\
\text { dissatisfied }\end{array}$ & Satisfied & $\mathrm{N}$ \\
\hline No Employees & $21.0 \%$ & $21.8 \%$ & $29.7 \%$ & $27.5 \%$ & 3278 \\
\hline 1 to 5 Employees & $19.5 \%$ & $24.4 \%$ & $27.2 \%$ & $28.9 \%$ & 3792 \\
\hline 6 or more Employees & $17.6 \%$ & $27.3 \%$ & $23.9 \%$ & $31.2 \%$ & 3625 \\
\hline Chi-square & 61.279 & [6] & $(0.000)$ & & \\
\hline $\begin{array}{l}\text { Goodman and Kruskal's } \\
\text { Gamma }\end{array}$ & 0.022 & $\{1.835\}$ & $(0.067)$ & & \\
\hline All & $19.3 \%$ & $24.6 \%$ & $26.8 \%$ & $29.3 \%$ & 10,695 \\
\hline
\end{tabular}

Notes: Degrees of freedom in squared brackets; $p$-values in parentheses; t-values in braces 
Table 2 -Extent of Agreement that Local Authorities Communicate and Collaborate with the Third Sector

\begin{tabular}{|c|c|c|c|c|c|c|}
\hline $\begin{array}{c}\text { Panel a - Local } \\
\text { Authorities Value the } \\
\text { Output of the Third } \\
\text { Sector }\end{array}$ & $\begin{array}{l}\text { Strongly } \\
\text { disagree }\end{array}$ & $\begin{array}{l}\text { Tend to } \\
\text { disagree }\end{array}$ & $\begin{array}{l}\text { Neither } \\
\text { agree nor } \\
\text { disagree }\end{array}$ & $\begin{array}{l}\text { Tend to } \\
\text { agree }\end{array}$ & $\begin{array}{l}\text { Strongly } \\
\text { agree }\end{array}$ & $\mathrm{N}$ \\
\hline No Employees & $8.1 \%$ & $14.7 \%$ & $19.9 \%$ & $42.8 \%$ & $14.6 \%$ & 3278 \\
\hline 1 to 5 Employees & $6.7 \%$ & $14.3 \%$ & $15.4 \%$ & $44.6 \%$ & $19.0 \%$ & 3792 \\
\hline 6 or more Employees & $4.7 \%$ & $12.4 \%$ & $11.4 \%$ & $49.5 \%$ & $21.9 \%$ & 3625 \\
\hline Chi-square & 186.58 & [8] & $(0.000)$ & & & \\
\hline $\begin{array}{l}\text { Goodman and Kruskal's } \\
\text { Gamma }\end{array}$ & 0.144 & $\{12.152\}$ & $(0.000)$ & & & \\
\hline All & $6.5 \%$ & $13.8 \%$ & $15.4 \%$ & $45.7 \%$ & $18.6 \%$ & 10,695 \\
\hline $\begin{array}{c}\text { Panel b- Local } \\
\text { Authorities Understand } \\
\text { the Nature of the Third } \\
\text { Sector } \\
\end{array}$ & $\begin{array}{l}\text { Strongly } \\
\text { disagree }\end{array}$ & $\begin{array}{l}\text { Tend to } \\
\text { disagree }\end{array}$ & $\begin{array}{l}\text { Neither } \\
\text { agree nor } \\
\text { disagree }\end{array}$ & $\begin{array}{l}\text { Tend to } \\
\text { agree }\end{array}$ & $\begin{array}{l}\text { Strongly } \\
\text { agree }\end{array}$ & $\mathrm{N}$ \\
\hline No Employees & $8.8 \%$ & $17.4 \%$ & $17.5 \%$ & $43.4 \%$ & $12.9 \%$ & 3278 \\
\hline 1 to 5 Employees & $7.8 \%$ & $20.3 \%$ & $16.5 \%$ & $40.4 \%$ & $15.0 \%$ & 3792 \\
\hline 6 or more Employees & $6.3 \%$ & $21.0 \%$ & $13.5 \%$ & $43.9 \%$ & $15.3 \%$ & 3625 \\
\hline Chi-square & 60.706 & [8] & $(0.000)$ & & & \\
\hline $\begin{array}{l}\text { Goodman and Kruskal's } \\
\text { Gamma }\end{array}$ & 0.031 & $\{2.636\}$ & $(0.008)$ & & & \\
\hline All & $7.6 \%$ & $19.7 \%$ & $15.8 \%$ & $42.5 \%$ & $14.4 \%$ & 10,695 \\
\hline $\begin{array}{l}\text { Panel c - Local } \\
\text { Authorities Consult the } \\
\text { Third Sector on Issues }\end{array}$ & $\begin{array}{l}\text { Strongly } \\
\text { disagree }\end{array}$ & $\begin{array}{l}\text { Tend to } \\
\text { disagree }\end{array}$ & $\begin{array}{l}\text { Neither } \\
\text { agree nor } \\
\text { disagree }\end{array}$ & $\begin{array}{l}\text { Tend to } \\
\text { agree }\end{array}$ & $\begin{array}{l}\text { Strongly } \\
\text { agree }\end{array}$ & $\mathrm{N}$ \\
\hline No Employees & $16.3 \%$ & $24.3 \%$ & $24.8 \%$ & $26.5 \%$ & $8.1 \%$ & 3278 \\
\hline 1 to 5 Employees & $13.2 \%$ & $23.9 \%$ & $23.6 \%$ & $30.2 \%$ & $9.1 \%$ & 3792 \\
\hline 6 or more Employees & $10.5 \%$ & $24.0 \%$ & $20.3 \%$ & $35.4 \%$ & $9.8 \%$ & 3625 \\
\hline Chi-square & 109.69 & [8] & $(0.000)$ & & & \\
\hline $\begin{array}{l}\text { Goodman and Kruskal's } \\
\text { Gamma }\end{array}$ & 0.096 & $\{8.398\}$ & $(0.000)$ & & & \\
\hline All & $13.2 \%$ & $24.0 \%$ & $22.9 \%$ & $30.8 \%$ & $9.0 \%$ & 10,695 \\
\hline $\begin{array}{c}\text { Panel d - Local } \\
\text { Authorities Involve Third } \\
\text { Sector on Policy } \\
\text { Development }\end{array}$ & $\begin{array}{l}\text { Strongly } \\
\text { disagree }\end{array}$ & $\begin{array}{l}\text { Tend to } \\
\text { disagree }\end{array}$ & $\begin{array}{l}\text { Neither } \\
\text { agree nor } \\
\text { disagree }\end{array}$ & $\begin{array}{l}\text { Tend to } \\
\text { agree }\end{array}$ & $\begin{array}{l}\text { Strongly } \\
\text { agree }\end{array}$ & $\mathrm{N}$ \\
\hline No Employees & $17.3 \%$ & $26.6 \%$ & $27.9 \%$ & $22.3 \%$ & $5.9 \%$ & 3278 \\
\hline 1 to 5 Employees & $15.2 \%$ & $26.8 \%$ & $26.1 \%$ & $25.5 \%$ & $6.4 \%$ & 3792 \\
\hline 6 or more Employees & $12.6 \%$ & $27.4 \%$ & $22.8 \%$ & $29.4 \%$ & $7.9 \%$ & 3625 \\
\hline Chi-square & 88.012 & [8] & $(0.000)$ & & & \\
\hline $\begin{array}{l}\text { Goodman and Kruskal's } \\
\text { Gamma }\end{array}$ & 0.079 & $\{6.905\}$ & $(0.000)$ & & & \\
\hline All & $15.0 \%$ & $26.9 \%$ & $25.5 \%$ & $25.8 \%$ & $6.8 \%$ & 10,695 \\
\hline
\end{tabular}

Notes: Degrees of freedom in squared brackets; p-values in parentheses; t-value in braces 
Table 3 - Regression of overall perceptions regarding the ease of accessing and maintaining Local Authority grant funding

\begin{tabular}{|c|c|c|c|}
\hline & No Employ' & $\begin{array}{c}1 \text { to } 5 \\
\text { Employ' }\end{array}$ & 6+ Employ' \\
\hline \multicolumn{4}{|l|}{$\underline{\text { Income }}$} \\
\hline In Income & $\begin{array}{c}0.015 \\
(0.029)\end{array}$ & $\begin{array}{l}-0.005 \\
(0.473)\end{array}$ & $\begin{array}{l}-0.018 \\
(0.013)\end{array}$ \\
\hline \multicolumn{4}{|l|}{$\underline{\text { Volunteers }}$} \\
\hline In Volunteers & $\begin{array}{l}-0.036 \\
(0.026)\end{array}$ & $\begin{array}{l}-0.020 \\
(0.147)\end{array}$ & $\begin{array}{l}-0.036 \\
(0.001)\end{array}$ \\
\hline \multicolumn{4}{|l|}{ Main Users of Services } \\
\hline Those from Minority Groups & $\begin{array}{l}-0.051 \\
(0.004)\end{array}$ & $\begin{array}{l}-0.035 \\
(0.000)\end{array}$ & $\begin{array}{l}-0.024 \\
(0.019)\end{array}$ \\
\hline General Public & $\begin{array}{c}0.051 \\
(0.002)\end{array}$ & $\begin{array}{c}0.024 \\
(0.144)\end{array}$ & $\begin{array}{l}-0.024 \\
(0.171)\end{array}$ \\
\hline $\begin{array}{l}\text { Those with Physical and Mental } \\
\text { Disabilities }\end{array}$ & $\begin{array}{l}-0.033 \\
(0.029)\end{array}$ & $\begin{array}{l}-0.024 \\
(0.066)\end{array}$ & $\begin{array}{l}-0.017 \\
(0.142)\end{array}$ \\
\hline Young and Carers & $\begin{array}{l}-0.038 \\
(0.014)\end{array}$ & $\begin{array}{l}-0.012 \\
(0.399)\end{array}$ & $\begin{array}{c}0.032 \\
(0.031)\end{array}$ \\
\hline \multicolumn{4}{|l|}{ Legal Form } \\
\hline Non-Charity & $\begin{array}{l}-0.232 \\
(0.000)\end{array}$ & $\begin{array}{l}-0.172 \\
(0.000)\end{array}$ & $\begin{array}{l}-0.029 \\
(0.502)\end{array}$ \\
\hline \multicolumn{4}{|l|}{$\frac{\text { Area of Activity }}{\text { (base category - Local) }}$} \\
\hline International/National & $\begin{array}{l}-0.189 \\
(0.003)\end{array}$ & $\begin{array}{l}-0.118 \\
(0.050)\end{array}$ & $\begin{array}{l}-0.019 \\
(0.736)\end{array}$ \\
\hline Regional & $\begin{array}{l}-0.118 \\
(0.033)\end{array}$ & $\begin{array}{l}-0.119 \\
(0.010)\end{array}$ & $\begin{array}{c}-0.109 \\
(0.007)\end{array}$ \\
\hline
\end{tabular}

Notes: $p$-values in parentheses; emboldened values significant at 5 percent level 
Table 3 - continued

\begin{tabular}{|c|c|c|c|}
\hline & No Employ' & $\begin{array}{l}1 \text { to } 5 \\
\text { Employ' }\end{array}$ & 6+ Employ' \\
\hline \multicolumn{4}{|l|}{$\frac{\text { Index of Multiple Deprivation }}{\text { (base category IMD } 5-10)}$} \\
\hline IMD 1 - 5 & $\begin{array}{c}0.032 \\
(0.842)\end{array}$ & $\begin{array}{c}0.244 \\
(0.029)\end{array}$ & $\begin{array}{c}0.047 \\
(0.649)\end{array}$ \\
\hline IMD 10 - 15 & $\begin{array}{c}0.078 \\
(0.598)\end{array}$ & $\begin{array}{c}0.131 \\
(0.185)\end{array}$ & $\begin{array}{c}0.078 \\
(0.352)\end{array}$ \\
\hline IMD 15 - 25 & $\begin{array}{c}0.019 \\
(0.897)\end{array}$ & $\begin{array}{c}0.184 \\
(0.059)\end{array}$ & $\begin{array}{c}0.037 \\
(0.654)\end{array}$ \\
\hline IMD 25 - 50 & $\begin{array}{l}-0.011 \\
(0.942)\end{array}$ & $\begin{array}{c}0.081 \\
(0.393)\end{array}$ & $\begin{array}{c}0.053 \\
(0.497)\end{array}$ \\
\hline IMD $50-65$ & $\begin{array}{l}-0.157 \\
(0.283)\end{array}$ & $\begin{array}{l}-0.051 \\
(0.581)\end{array}$ & $\begin{array}{l}-0.015 \\
(0.838)\end{array}$ \\
\hline IMD 65+ & $\begin{array}{l}-0.170 \\
(0.305)\end{array}$ & $\begin{array}{c}0.002 \\
(0.983)\end{array}$ & $\begin{array}{l}-0.007 \\
(0.930)\end{array}$ \\
\hline $\begin{array}{l}\text { Successfully Bid for Local Authority } \\
\text { Money }\end{array}$ & $\begin{array}{c}0.728 \\
(0.000)\end{array}$ & $\begin{array}{c}0.562 \\
(0.000)\end{array}$ & $\begin{array}{c}0.407 \\
(0.000)\end{array}$ \\
\hline Constant & $\begin{array}{l}-0.478 \\
(0.003)\end{array}$ & $\begin{array}{l}-\mathbf{0 . 3 8 2} \\
(0.002)\end{array}$ & $\begin{array}{l}-0.010 \\
(0.933)\end{array}$ \\
\hline$N$ & 3278 & 3792 & 3625 \\
\hline Pseudo $R^{2}$ & 0.170 & 0.108 & 0.052 \\
\hline F-test & $\begin{array}{l}41.711 \\
(0.000)\end{array}$ & $\begin{array}{l}28.437 \\
(0.000)\end{array}$ & $\begin{array}{l}12.343 \\
(0.000)\end{array}$ \\
\hline
\end{tabular}

Notes: $p$-values in parentheses; emboldened values significant at 5 percent level 
Table 4 - Regression of overall perceptions regarding the communication and understanding of Local Authorities of the Third Sector

\begin{tabular}{lccc}
\hline & No Employ' & $\begin{array}{c}1 \text { to } 5 \\
\text { Employ' }\end{array}$ & 6 + Employ' \\
\hline Income & & & \\
In Income & 0.003 & -0.003 & 0.006 \\
Volunteers & $(0.621)$ & $(0.727)$ & $(0.376)$ \\
In Volunteers & & & \\
Main Users of Services & 0.006 & -0.015 & 0.002 \\
Those from Minority Groups & $(0.726)$ & $(0.299)$ & $(0.847)$ \\
& & & \\
General Public & 0.029 & -0.006 & 0.009 \\
Those with Physical and Mental & $(0.104)$ & $(0.587)$ & $(0.382)$ \\
Disabilities & -0.018 & -0.021 & -0.020 \\
Young and Carers & $(0.293)$ & $(0.203)$ & $(0.250)$ \\
Legal Form & -0.002 & -0.020 & 0.004 \\
& $(0.919)$ & $(0.134)$ & $(0.709)$ \\
Non-Charity & -0.001 & 0.010 & 0.021 \\
Area of Activity & $(0.941)$ & $(0.507)$ & $(0.160)$ \\
(base category - Local) & & & \\
International/National & -0.121 & -0.139 & 0.067 \\
& $(0.016)$ & $(0.001)$ & $(0.122)$ \\
Regional & & & \\
\hline & & & \\
& -0.113 & -0.266 & -0.348 \\
& $(0.081)$ & $(0.000)$ & $(0.000)$ \\
& -0.014 & -0.117 & -0.192 \\
& $(0.811)$ & $(0.015)$ & $(0.000)$ \\
\hline
\end{tabular}

Notes: $p$-values in parentheses; emboldened values significant at 5 percent level 
Table 4 - continued

\begin{tabular}{|c|c|c|c|}
\hline & No Employ' & $\begin{array}{l}1 \text { to } 5 \\
\text { Employ' }\end{array}$ & 6+ Employ' \\
\hline \multicolumn{4}{|l|}{$\frac{\text { Index of Multiple Deprivation }}{\text { (base category IMD } 5-10 \text { ) }}$} \\
\hline IMD 1 - 5 & $\begin{array}{l}-0.122 \\
(0.451)\end{array}$ & $\begin{array}{l}-0.032 \\
(0.785)\end{array}$ & $\begin{array}{c}0.073 \\
(0.483)\end{array}$ \\
\hline IMD $10-15$ & $\begin{array}{l}-0.132 \\
(0.384)\end{array}$ & $\begin{array}{c}0.166 \\
(0.105)\end{array}$ & $\begin{array}{c}0.113 \\
(0.190)\end{array}$ \\
\hline IMD $15-25$ & $\begin{array}{l}-0.174 \\
(0.249)\end{array}$ & $\begin{array}{c}0.138 \\
(0.170)\end{array}$ & $\begin{array}{c}0.080 \\
(0.336)\end{array}$ \\
\hline IMD $25-50$ & $\begin{array}{l}-0.097 \\
(0.520)\end{array}$ & $\begin{array}{c}0.068 \\
(0.486)\end{array}$ & $\begin{array}{c}0.043 \\
(0.589)\end{array}$ \\
\hline IMD $50-65$ & $\begin{array}{l}-0.111 \\
(0.460)\end{array}$ & $\begin{array}{c}0.103 \\
(0.282)\end{array}$ & $\begin{array}{c}0.032 \\
(0.671)\end{array}$ \\
\hline IMD 65+ & $\begin{array}{l}-0.011 \\
(0.946)\end{array}$ & $\begin{array}{c}0.105 \\
(0.324)\end{array}$ & $\begin{array}{l}-0.030 \\
(0.731)\end{array}$ \\
\hline $\begin{array}{l}\text { Successfully Bid for Local Authority } \\
\text { Money }\end{array}$ & $\begin{array}{c}0.404 \\
(0.000)\end{array}$ & $\begin{array}{c}0.450 \\
(0.000)\end{array}$ & $\begin{array}{c}0.467 \\
(0.000)\end{array}$ \\
\hline Constant & $\begin{array}{l}-0.334 \\
(0.043)\end{array}$ & $\begin{array}{l}-0.380 \\
(0.003)\end{array}$ & $\begin{array}{c}-0.248 \\
(0.047)\end{array}$ \\
\hline$N$ & 3278 & 3792 & 3625 \\
\hline$R^{2}$ & 0.048 & 0.070 & 0.066 \\
\hline F-test & $\begin{array}{l}10.261 \\
(0.000)\end{array}$ & $\begin{array}{l}17.864 \\
(0.000)\end{array}$ & $\begin{array}{l}15.874 \\
(0.000)\end{array}$ \\
\hline
\end{tabular}

Notes: p-values in parentheses; emboldened values significant at 5 percent level 
Appendix Table A1 - Factor loadings for principal component analysis of opinions on application process and communication with Local Authorities

\begin{tabular}{lcc}
\hline & 1 & 2 \\
\hline $\begin{array}{l}\text { Local Authority Consults on Issues that } \\
\text { affect Organization }\end{array}$ & 0.844 & 0.207 \\
$\begin{array}{l}\text { Local Authority involves Organization } \\
\text { in Development of Policy }\end{array}$ & 0.831 & 0.233 \\
$\begin{array}{l}\text { Understand Nature and Role of } \\
\text { Organization }\end{array}$ & 0.828 & 0.207 \\
$\begin{array}{l}\text { Value Organization's Outputs } \\
\text { Satisfaction with Process of Apply for }\end{array}$ & 0.821 & 0.179 \\
$\begin{array}{l}\text { Grants } \\
\text { Satisfaction with Support and Advice } \\
\text { Available for Applying for Grants } \\
\text { Satisfaction with Administration of }\end{array}$ & 0.165 & 0.872 \\
Receiving and Maintaining Grants & 0.271 & 0.808 \\
Bartlett's Test of Sphericity & 0.189 & 0.800 \\
& & \\
& 46765.0 & \\
Kaiser-Meyer-Olkin & {$[21]$} & \\
\hline
\end{tabular}


Appendix Table A2 - Factor loadings for principal component analysis of the main users of individual third sector organizations

\begin{tabular}{|c|c|c|c|c|}
\hline & 1 & 2 & 3 & 4 \\
\hline General Public/Everyone (Reversed) & -0.020 & -0.005 & 0.196 & 0.477 \\
\hline Women & 0.066 & 0.889 & -0.051 & 0.015 \\
\hline Men & 0.071 & 0.894 & -0.039 & 0.018 \\
\hline Older people & 0.020 & 0.498 & 0.159 & -0.024 \\
\hline Children (Under 16 Years of Age) & -0.027 & -0.057 & -0.086 & 0.833 \\
\hline Young People (Aged 16 to 24 Years) & 0.133 & 0.086 & -0.129 & 0.695 \\
\hline Those with physical disabilities & -0.009 & 0.032 & 0.737 & 0.098 \\
\hline Those requiring particular physical help & 0.081 & 0.076 & 0.572 & -0.030 \\
\hline Those with learning difficulties & 0.092 & -0.015 & 0.670 & 0.102 \\
\hline Those with mental health needs & 0.286 & 0.037 & 0.493 & -0.049 \\
\hline Members of ethnic minorities & 0.397 & 0.095 & 0.064 & 0.108 \\
\hline People with a particular financial need & 0.334 & 0.013 & 0.082 & -0.002 \\
\hline Asylum seekers and refugees & 0.481 & 0.026 & 0.010 & 0.036 \\
\hline Homeless people & 0.531 & -0.044 & -0.037 & -0.042 \\
\hline Those with addiction problems & 0.594 & -0.024 & 0.034 & -0.047 \\
\hline Lesbian, gay, bisexual or transgender & 0.448 & 0.102 & 0.122 & 0.034 \\
\hline Socially excluded and vulnerable people & 0.499 & -0.022 & 0.126 & 0.041 \\
\hline Victims of crime & 0.514 & 0.070 & 0.067 & 0.030 \\
\hline Offenders and ex-offenders & 0.588 & -0.005 & -0.002 & 0.012 \\
\hline Carers and parents & 0.056 & -0.030 & 0.274 & 0.361 \\
\hline Bartlett's Test of Sphericity & 103,771 & [180] & $(0.000)$ & \\
\hline Kaiser-Meyer-Olkin & 0.664 & & & \\
\hline
\end{tabular}


